\title{
Molecular characterization of extended-spectrum $\beta$-lactamase-producing Escherichia coli isolated from postpartum uterine infection in dairy cattle in India
}

\author{
Samiksha Agrawal ${ }^{1}$, Ajay Pratap Singh ${ }^{2}$, Rashmi Singh², Raktim Saikia ${ }^{3}$, Soumen Choudhury ${ }^{3}$, Amit Shukla ${ }^{3}$, \\ Shyama N. Prabhu ${ }^{4}$ and Jitendra Agrawal ${ }^{5}$
}

1. College of Biotechnology, Uttar Pradesh Pandit Deen Dayal Upadhyaya Pashu Chikitsa Vigyan Vishwavidhyalaya Ewam Gau Anusandhan Sansthan Mathura, Uttar Pradesh, India; 2. Department of Veterinary Microbiology, Uttar Pradesh Pandit Deen Dayal Upadhyaya Pashu Chikitsa Vigyan Vishwavidhyalaya Ewam Gau Anusandhan Sansthan Mathura, Uttar Pradesh, India; 3. Department of Veterinary Pharmacology, Uttar Pradesh Pandit Deen Dayal Upadhyaya Pashu Chikitsa Vigyan Vishwavidhyalaya Ewam Gau Anusandhan Sansthan Mathura, Uttar Pradesh, India; 4. Department of Veterinary Pathology, Uttar Pradesh Pandit Deen Dayal Upadhyaya Pashu Chikitsa Vigyan Vishwavidhyalaya Ewam Gau Anusandhan Sansthan Mathura, Uttar Pradesh, India; 5. Department of Animal Reproduction and Gynecology, College of Veterinary Science and Animal Husbandry, Uttar Pradesh Pandit Deen Dayal Upadhyaya Pashu Chikitsa Vigyan Vishwavidhyalaya Ewam Gau Anusandhan Sansthan Mathura, Uttar Pradesh, India.

Corresponding author: Ajay Pratap Singh, e-mail: drajay_vet@yahoo.co.in

Co-authors: SA: samikshaagrawal994@gmail.com, RS: madan_rs@rediffmail.com, RaS: drraktimsaikia@gmail.com, SC: chsoumenpharma@gmail.com, AS: princu.dr@gmail.com, SNP: kris_shyama@yahoo.co.in, JA: jituvet11@gmail.com Received: 06-09-2020, Accepted: 12-12-2020, Published online: 23-01-2021

doi: www.doi.org/10.14202/vetworld.2021.200-209 How to cite this article: Agrawal S, Singh AP, Singh R, Saikia R, Choudhury S, Shukla A, Prabhu SN, Agrawal J (2021) Molecular characterization of extended-spectrum $\beta$-lactamaseproducing Escherichia coli isolated from postpartum uterine infection in dairy cattle in India, Veterinary World, 14(1): 200-209.

\begin{abstract}
Background and Aim: Selection and dissemination of plasmid-encoded extended-spectrum $\beta$-lactamase (ESBL) among Enterobacteriaceae confers resistance to beta-lactam antibiotics. The purpose of this study was to determine the prevalence and molecular characteristics of ESBL-producing organisms isolated from dairy cattle with a uterine infection.

Materials and Methods: Bacterial isolates $(n=62)$ were characterized by biochemical test for genus and species determination. Antimicrobial susceptibility tests were performed by Kirby-Bauer disk diffusion method using panel of antibiotics for initial screening of ESBL organism. Phenotypic confirmation of ESBL-suspected strains was done by combination disk method and double-disk method. Multiplex polymerase chain reaction (PCR) was carried out for phylogrouping of Escherichia coli isolates as well as for genotyping ESBL genes. Enterobacterial repetitive intergenic consensus-PCR method was used for genotypic characterization of isolates.
\end{abstract}

Results: Antibiotic susceptibility profile of E. coli $(\mathrm{n}=40)$ isolates showed high rates of resistance for ampicillin $(95.0 \%)$, cefpodoxime $(97.5 \%)$, cefotaxime $(87.5 \%)$, and ceftriaxone $(70 \%)$. However, low rates of resistance were observed for cefoxitin (25\%), amoxicillin/clavulanic acid (20\%), ceftazidime (17.5\%), gentamicin (10\%), and ertapenem (7.5\%). A total of 39/40 E. coli isolates were confirmed as ESBL with Epsilometer test as well as the genotypic method and 28 (70\%) of them were multidrug-resistant. Genotype bla ${ }_{C T X-M}$ was observed as a predominant beta-lactamase type with the preponderance of CTX-M Group 1. The following combinations were observed: bla $a_{T E M}+b_{C T X-M}$ in 15 (36.2\%) isolates, bla $a_{T E M} / b l a_{S H V}$ in 8 $(5.2 \%)$ isolates, and $b l a_{C T X-M} / b l a_{S H V}$ in $6(5.2 \%)$ isolates. The phylogenetic grouping of $E$. coli strains revealed the highest prevalence for B1 $(22.0 \%)$ followed by A $(20 \%)$.

Conclusion: This report shows a high frequency of ESBL E. coli from cattle with postpartum uterine infections. These isolates showed reduced susceptibility to common antibiotics used for the treatment of uterine infections greater affecting the therapeutic outcome.

Keywords: antibiotic resistance, cattle, endometritis, extended-spectrum $\beta$-lactamases, microbiology.

\section{Introduction}

India is home to the world's largest bovine population which contributes to $\sim 19 \%$ of the global milk production in the world [1]. Postpartum uterine infections are one of the most important health-related problems in bovine causing significant economic

Copyright: Agrawal, et al. Open Access. This article is distributed under the terms of the Creative Commons Attribution 4.0 International License (http://creativecommons.org/licenses/ by/4.0/), which permits unrestricted use, distribution, and reproduction in any medium, provided you give appropriate credit to the original author(s) and the source, provide a link to the Creative Commons license, and indicate if changes were made. The Creative Commons Public Domain Dedication waiver (http:// creativecommons.org/publicdomain/zero/1.0/) applies to the data made available in this article, unless otherwise stated. losses to the dairy farmers due to the culling of the infertile animal, lower milk yield, and the rising cost of treatment [2]. Several different species of pathogens are known to be associated with clinical endometritis and infertility; however, the role of Escherichia coli has been stressed by several studies [3-7]. The traditional method for the treatment of bovine endometritis mainly involves the therapeutic use of antibiotics [8]. However, in recent years, the antimicrobial therapy of endometritis has resulted in higher proportions of treatment failures with inconsistent recovery rate. The attenuated effect of the therapeutic efficacy of antibiotics is largely contributed by the emergence of antimicrobial resistance [9]. 
Production of extended-spectrum $\beta$-lactamases (ESBLs) is the most frequent cause of resistance to $\beta$-lactam antibiotics in Gram-negative bacteria. ESBL genes generally carried on mobile genetic elements that facilitate its spread at fast rates among commensal and pathogenic bacteria in the herd and the environment. ESBL enzymes hydrolyze penicillins, cephalosporins, and the monobactam aztreonam rendering them ineffective. ESBL production is mainly mediated by $b l a_{T E M}$, $b l a_{S H V}$ and $b l a_{C T X-M}$ genes $[10,11]$. The CTX-M $\beta$-lactamases can be divided into five sublineages or groups: The CTX-M Group 1; CTX-M Group 2, CTX-M Group 8, CTX-M Group 9, and CTX-M Group 25 [12]. Recently, CTX-M has emerged as the most dominant genotype in Asia with the highest relative abundance of bla $_{C T X-M}$ Group 1 gene [13]. The ESBL-producing $E$. coli is an important constituent of the fecal flora of livestock, which may serve as a reservoir and source of transmission to humans by various direct and indirect means $[14,15]$. Recently, many studies have reported ESBL-producing E. coli isolated from cattle [16], poultry [17], and pigs [18]. Recent surveys suggest widespread colonization of ESBL Enterobacteriaceae in food-producing animals [19]. In India, ESBLproducing $E$. coli are mostly reported in food-producing animals and their environment through milk, meat, fecal samples, and bovine mastitis [17,20-25]. Metritis and endometritis are the major postpartum clinical conditions in bovine, characterized by inflammation of the uterus. Endometritis is an important contributor to bovine infertility extending the calving to conception interval, increasing the number of services per conception and the proportion of culls for failure to conceive.

Although there is growing a sense of urgency in reporting the prevalence of ESBLs from livestock in India, most of the studies are incoherent. Moreover, the epidemiological studies regarding the prevalence of ESBL-producing bacteria in bovine uterine infections are largely ignored. In this study, we report the prevalence of ESBL-producing E. coli in the uteri of cows with endometritis and further characterized them based on phenotypic and genotypic tests.

\section{Materials and Methods}

\section{Ethical approval}

This study was approved by the Institutional Animal Ethics committee of College of Veterinary Sciences, Uttar Pradesh Pandit Deen Dayal Upadhyaya Pashu Chikitsa Vigyan Vishwavidyalaya Evam Go Anusandhan Sansthan (DUVASU), Mathura, India with ref No. IAEC/18/23.

\section{Study location, period and sample collection}

Samples were collected from cases presented to the Veterinary Clinical Complex, College of Veterinary Sciences, DUVASU, Mathura, from May 2018 to September 2018. Puerperal metritis was diagnosed based on clinical observation such as an abnormally enlarged uterus and a fetid, watery, red-brown uterine discharge. The uterine discharge was obtained from each animal using a sterile swab by the double guarded method to prevent vaginal contamination. Each swab was transferred to a $20 \mathrm{~mL}$ collection vial containing 10 $\mathrm{mL}$ buffered peptone water, immediately placed on ice, and transported to the laboratory. Samples were incubated overnight at $37^{\circ} \mathrm{C}$ before inoculation.

\section{Isolation and identification of bacterial strains}

The pre-enriched samples were streaked onto MacConkey agar (Sigma-Aldrich) supplemented with cefotaxime and ceftazidime (HiMedia, India) at the concentration of $2 \mu \mathrm{g} / \mathrm{mL}$ each and incubated at $37^{\circ} \mathrm{C}$ for 18-24 h. One colony from each type was picked from primary growth and subcultured on the MacConkey agar plate supplemented with both cefotaxime and ceftazidime at the final concentration of $1 \mu \mathrm{g} / \mathrm{mL}$. Purified isolates were identified using the procedures described by Cowan and Steel [26]. Biochemically confirmed isolates were stored in trypticase soy broth (TSB; SigmaAldrich) containing $30 \%$ glycerol at $-80^{\circ} \mathrm{C}$.

\section{Antibiotic susceptibility test}

Antimicrobial susceptibility test was performed for all E. coli isolates by standard Kirby-Bauer disk diffusion method using Mueller-Hinton agar (Sigma-Aldrich, USA) as per Clinical and Laboratory Standards Institute guidelines [27]. Briefly, three to four well-isolated colonies from overnight grown culture plates were transferred to sterile saline with a loop. The bacterial suspension was adjusted to give turbidity equivalent to $0.5 \mathrm{McF}$ arland standards corresponding to $1 \times 10^{8} \mathrm{CFU} / \mathrm{mL}$. A total volume of $1 \mathrm{~mL}$ of standardized inoculums were spread onto Mueller-Hinton agar plate and antimicrobial-impregnated disks (Becton Dickinson, Sparks, MD, USA) were placed. The used antibiotics were ertapenem $(10 \mu \mathrm{g})$, cefotaxime (30 $\mu \mathrm{g})$, ceftazidime $(30 \mu \mathrm{g})$, gentamicin $(10 \mu \mathrm{g})$, ampicillin $(10 \mu \mathrm{g})$, amoxicillin-clavulanate $(10 \mu \mathrm{g})$, ciprofloxacin $(5 \mu \mathrm{g})$, cefoxitin $(30 \mu \mathrm{g})$, ceftriaxone $(30 \mu \mathrm{g})$, and cefpodoxime $(10 \mu \mathrm{g})$. Zone of inhibition was measured in $\mathrm{mm}$ and interpreted as sensitive, intermediate, or resistant. E. coli ATCC 25922 (ESBL-negative strain) and Klebsiella pneumoniae ATCC 700603 (ESBLpositive strain) were used as control strains (Table-1). Multiple antibiotic resistance (MAR) index was determined for each isolate using the formula $M A R=a / b$, where a represents the number of antibiotics to which the test isolate depicted resistance and $\mathrm{b}$ represents the total number of antibiotics to which the test isolate has been evaluated for susceptibility.

\section{Phenotypic detection of ESBL production}

All E. coli isolates suspected of producing ESBL based on zone diameter breakpoints corresponding to resistant phenotype were included in the study. All the ESBL-suspected isolates were grown on trypticase soy agar (TSA, Sigma-Aldrich) for an overnight incubation, before phenotypic testing by combination disk method, double-disk diffusion method, and ESBL MIC reduction E-test as previously described 
Table-1: AST zone diameters for control strain E. coli $\left(\right.$ ATCC $\left.^{\circledR} 25922^{\mathrm{TM}}\right)$ and the test $E$. coli isolates* used in this assay.

\begin{tabular}{|c|c|c|c|c|c|c|c|}
\hline \multirow[t]{2}{*}{ Antibiotic } & \multirow[t]{2}{*}{ Disk code } & \multirow{2}{*}{$\begin{array}{c}\text { Antibiotic } \\
\text { concentration } \\
(\mu \mathrm{g})\end{array}$} & \multirow{2}{*}{$\begin{array}{l}\text { Control } \\
\text { strain zone } \\
\text { diameter } \\
\text { range } \\
(\mathrm{mm})\end{array}$} & \multirow{2}{*}{$\begin{array}{l}\text { Control } \\
\text { strain } \\
\text { diameter } \\
\text { observed } \\
(\mathbf{m m})\end{array}$} & \multicolumn{3}{|c|}{ Test zone diameters $(\mathrm{mm})$} \\
\hline & & & & & Resistant & Intermediate & Susceptible \\
\hline $\begin{array}{l}\text { Amoxicillin/ } \\
\text { clavulanic acid }\end{array}$ & AmC-30 & $20 / 10$ & $18-24$ & 22 & $\leq 13$ & $14-17$ & $\geq 18$ \\
\hline Ampicillin & AM-10 & 10 & $16-22$ & 20 & $\leq 13$ & $14-16$ & $\geq 17$ \\
\hline Cefotaxime & CTX-30 & 30 & $29-35$ & 34 & $\leq 14$ & $15-22$ & $\geq 23$ \\
\hline Ceftazidime & CAZ-30 & 30 & $25-32$ & 29 & $\leq 14$ & $15-17$ & $\geq 18$ \\
\hline Cefpodoxime & CPD-10 & 10 & $23-28$ & 25 & $\leq 17$ & $18-20$ & $\geq 17$ \\
\hline Ceftriaxone & CRO-30 & 30 & $29-35$ & 29 & $\leq 13$ & $14-20$ & $\geq 21$ \\
\hline Cefoxitin & FOX-30 & 30 & $23-29$ & 24 & $\leq 14$ & $15-17$ & $\geq 18$ \\
\hline Ciprofloxacin & CIP-5 & 5 & $30-40$ & 30 & $\leq 15$ & $16-20$ & $\geq 21$ \\
\hline Gentamicin & GM-10 & 10 & $19-26$ & 17 & $\leq 12$ & $13-14$ & $\geq 15$ \\
\hline Ertapenem & ETP-10 & 10 & $29-36$ & 32 & $\leq 15$ & $16-18$ & $\geq 19$ \\
\hline
\end{tabular}

*Adapted from M100, Performance Standards for AST; $27^{\text {th }}$ edition, (Published by Clinical and Laboratory Standards Institute, CLSI 2017, Pennsylvania, USA. AST=Antimicrobial susceptibility testing, E. coli=Escherichia coli

or with some modifications. E. coli ATCC 25922 (ESBL-negative strain) and $K$. pneumoniae ATCC 700603 (ESBL-positive strain) were used as control strains.

\section{Analysis of antimicrobial resistance genes}

The DNA extraction was performed using heat lysis (Snap-chill method) method. Briefly, loopful of bacterial culture was suspended with $200 \mu \mathrm{L}$ nuclease-free water thoroughly in microcentrifuge tube followed by heating in a boiling water bath for $10 \mathrm{~min}$. Boiled cell lysate was centrifuged at $12,000 \mathrm{rpm}$ for $2 \mathrm{~min}$. Three microliters of supernatant were used as a template for polymerase chain reaction (PCR) reaction. DNA isolated was subjected to a target amplification of ESBL-associated genes encoding CTX-M, TEM, and SHV using previously described oligonucleotide primers as described in Table-2. Multiplex PCR was also performed for the identification of CTX-M genes using specific primers designed for identifying CTX-M groups (individually, CTX-M Groups 1,2, and 9, and, together, Groups 8 and 25). A $25 \mu \mathrm{L}$ reaction mixture containing $12.5 \mu \mathrm{L}$ DreamTaq Master Mix, a variable concentration of specific group primers (Table-2) and $2 \mu \mathrm{L}$ of isolated DNA template were used. Amplification was carried involving initial denaturation at $94^{\circ} \mathrm{C}$ for $10 \mathrm{~min}$ and 30 cycles of denaturation at $94^{\circ} \mathrm{C}$ for $40 \mathrm{~s}$, at variable annealing temperature for each primer (Table-2) for $40 \mathrm{~s}$, and extension at $72^{\circ} \mathrm{C}$ for 1 min followed by final elongation step at $72^{\circ} \mathrm{C}$ for $7 \mathrm{~min}$. Amplicons were visualized after running at $80 \mathrm{~V}$ for $2 \mathrm{~h}$ on $2 \%$ agarose gel containing ethidium bromide $(0.5 \mu \mathrm{g} / \mathrm{mL})$ with a $100 \mathrm{bp}$ DNA ladder as a size marker. K. pneumonia ATCC 700603 (ESBLs positive strain) was used as a positive control.

\section{Phylogenetic determination of $\beta$-lactamase-produc- ing $E$. coli isolates}

A quadruplex PCR assay targeting the chuA and $y j a A$ genes, $T s p E 4$ and $\operatorname{arp} A$, and a simplex PCR using Group E and Group C specific primers using
trpA as an internal control was carried out as proposed by Clermont et al. [28]. The primers sequences and products size are listed in Table-2 [28-31]. PCR reactions were performed under the following condition: Denaturation at $94^{\circ} \mathrm{C}$ for $4 \mathrm{~min}, 30$ cycles of $5 \mathrm{~s}$ at $94^{\circ} \mathrm{C}$ and $20 \mathrm{~s}$ at $57^{\circ} \mathrm{C}$ (Group E) or $59^{\circ} \mathrm{C}$ (quadruplex and Group $\mathrm{C}$ ), and a final extension at $72^{\circ} \mathrm{C}$ for $5 \mathrm{~s}$ followed by final elongation step at $72^{\circ} \mathrm{C}$ for $7 \mathrm{~min}$.

\section{Enterobacterial repetitive intergenic consensus (ERIC)-PCR}

ERIC-PCR reactions were performed in $20 \mu \mathrm{L}$ volumes containing $50 \mathrm{pmol}$ of each primer (final concentration), $10 \mu \mathrm{L}$ of the master mix, $1.5 \mu \mathrm{L}$ of $\mathrm{MgCl}_{2}, 2 \mu \mathrm{L}$ of template DNA, and $3.5 \mu \mathrm{L}$ of deionized water. PCR amplification was achieved by initial denaturation at $94^{\circ} \mathrm{C}$ for $30 \mathrm{~s}$, annealing at $50^{\circ} \mathrm{C}$ for 45 $\mathrm{s}$, and extension at $72^{\circ} \mathrm{C}$ for $3 \mathrm{~min}$ followed by final elongation step at $72^{\circ} \mathrm{C}$ for $7 \mathrm{~min}$. PCR products were electrophoresed using 1.5\% agarose (Puregene) gel electrophoresis at $80 \mathrm{~V}$ for $180 \mathrm{~min}$ then visualized under UV in a gel documentation system. The image was analyzed by GelJ software (https://sourceforge. net/projects/gelj/).

\section{Results}

\section{Endometritis-associated uterine Enterobacteriaceae}

Uterine sampling of cows $(\mathrm{n}=34)$ and buffaloes $(n=36)$ with clinical endometritis identified a total of 62 bacterial isolates. The isolates are distributed as follows: E. coli was found to be the most common identified Enterobacteriaceae, with occurrence of $64.5 \%$ $(\mathrm{n}=40)$, Klebsiella spp. 11.2\% ( $\mathrm{n}=7)$, Citrobacter spp. $8.06 \%(\mathrm{n}=5)$, Serratia spp. $6.45 \%(\mathrm{n}=4)$, and Enterobacter spp. $3.22 \% \quad(n=2)$. Among non-fermentative Gram-negative bacilli, Pseudomonas spp. $3.22 \%(n=2)$ was recovered. Two isolates could not be identified by the biochemical tests.

\section{Antibiotic susceptibility}

The results of antibiotic susceptibility of the 40 E. coli isolates are presented in Figure-1. The majority 


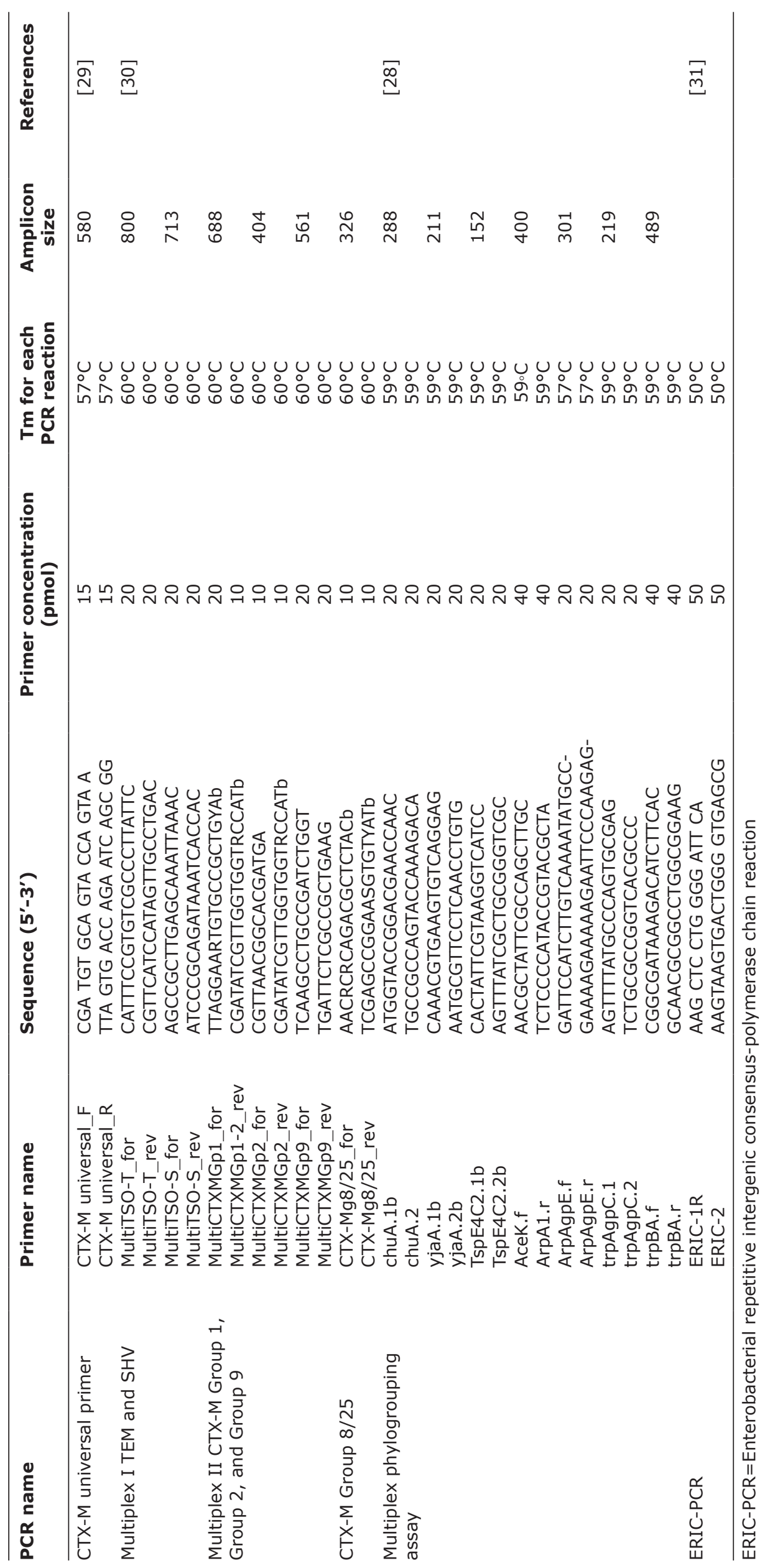




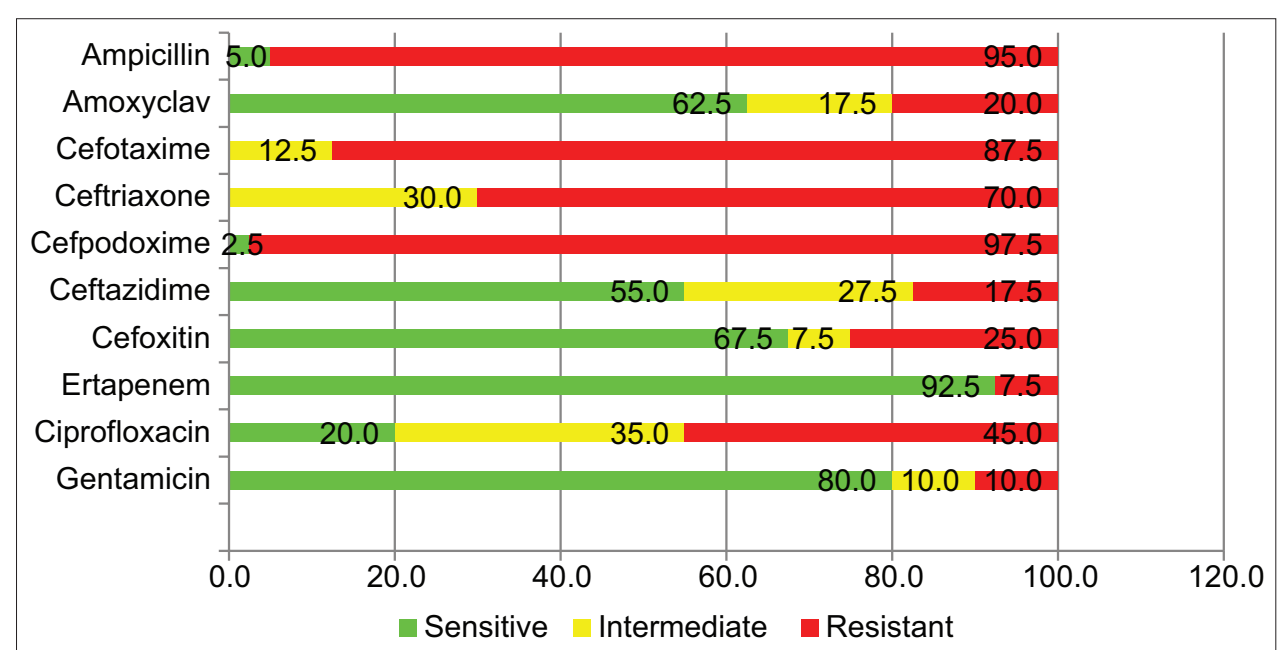

Figure-1: Percentage of uterine isolates indicating resistance, intermediate resistance, and sensitive pattern for 10 different antibiotics.

of the isolates were resistant to several beta-lactam antimicrobials including ampicillin $(95.0 \%)$, cefpodoxime $(97.5 \%)$, cefotaxime $(87.5 \%)$, and ceftriaxone $(70 \%)$. All the isolates $(100 \%)$ were found resistant to at least one of the three cephalosporin antibiotics (cefotaxime, ceftriaxone, and cefpodoxime), while $70 \%(n=28)$ were resistant to the entire three cephalosporin antibiotics. However, a high rate of susceptibility was observed toward ceftazidime $(82.5 \%)$, amoxiclav (80\%), and cefoxitin (75\%). The isolates showed medium to a low level of resistance to non$\beta$-lactam antibiotics including ciprofloxacin $(45 \%)$ and gentamicin $(10 \%)$. Resistance to ertapenem was observed in $7.5 \%$ of the isolates. Of the $40 \mathrm{E}$. coli isolates, $70 \%$ were multidrug-resistant (MDR) and showed resistance to three or more different antibiotic groups (Figure-2). The mean MAR index for E. coli isolates was 0.47 (range 0.3-0.86).

\section{Phenotypic and genotypic characterization ESBL E. coli}

Out of 40 E. coli isolates, 31 (77.5\%) were phenotypically identified as presumptive ESBL producers. The ESBL E-test could confirm all the 40 isolates $(100 \%)$ as ESBL producers. Therefore, all E. coli isolates were genotyped using multiplex PCR (Figures-3 and 4). ESBL genotype-specific PCR assay could detect 39 (97.5\%) as ESBL producers. The overall prevalence of $b l a_{C T X-M}$, $b l a_{T E M}$, and $b l a_{S H V}$ genes among ESBL E. coli isolates recorded were $84.5 \%, 37.9 \%$, and $5.2 \%$, respectively. The coexistence of two of the genes was observed at the highest range with $b l a_{T E M}$ and $b l a_{C T X-M}$ in $15(36.2 \%)$ isolates followed by $b l a_{T E M}$ and $b l a_{S H V}$ in $8(5.2 \%)$ isolates and $b l a_{C T X-M}$ and $b l a_{S H V}$ in $6(5.2 \%)$ isolates. Notably, one isolate carried the three $\beta$-lactamase genes. Multiplex PCR for subgrouping of $b l a_{C T X-M}$ revealed $77.5 \%(\mathrm{n}=31)$ isolates was positive for $b l a_{C T X-M}$ Group 1 while $1(2.5 \%)$ was having amplicon specific for $b l a_{C T X-M}$ Group 2. For eight isolates, multiplex PCR for CTX-M grouping fails to give any result.

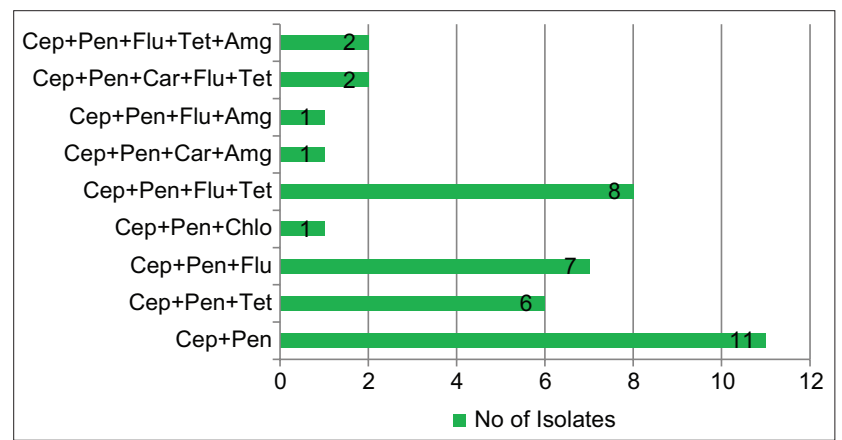

Figure-2: Antimicrobial resistance profile of Escherichia coli isolates obtained from infected bovine uterus $A m g=$ Aminoglycoside, Car=Carbapenam, $\mathrm{Cep}=\quad$ Cephalosporin, Chlo=Chloramphenicol, Flu $=$ Fluoroquinolones, Pen $=$ Penicillin, Tet $=$ Tetracycline.

\section{Phylogrouping of $E$. coli isolates}

All E. coli isolates were allocated to one of the eight phylogenetic groups (A, B1, B2, D, F, E, C, and Clad 1) according to Clermontet al. [28]. The results showed that $22.5 \%(\mathrm{n}=9)$ of these isolates belonged to phylogroup B1, $20 \%(\mathrm{n}=8)$ Group A, $12.5 \%(\mathrm{n}=5)$ each for Groups $\mathrm{C}$ and $\mathrm{D}, 7.5 \%(\mathrm{n}=5)$ Group F, and $2.5 \%(\mathrm{n}=1)$ each for Group E and Clad I.

\section{ERIC-PCR}

The clonal relatedness analysis of the $40 \mathrm{E}$. coli isolates was carried out by the ERIC-PCR fingerprint method. Eight $(20 \%)$ isolates were considered non-typeable by ERIC-PCR. ERIC-PCR generated several amplified products ranging from $\sim 150 \mathrm{bp}$ to $>1000 \mathrm{bp}$. The isolates produced different DNA profiles by ERIC-PCR ranging from 1 to 15 bands. Several bands were consistently present in all isolates showing clonal relatedness. The dendrogram was generated after analysis with GelJ software using UPGMA from the ERIC-PCR (Figure-5). Based on clustering, isolates could be grouped into six mini-clusters. Detailed analysis of bacterial strains from different clusters revealed that strains distributed across the cluster were genetically heterogeneous. No 


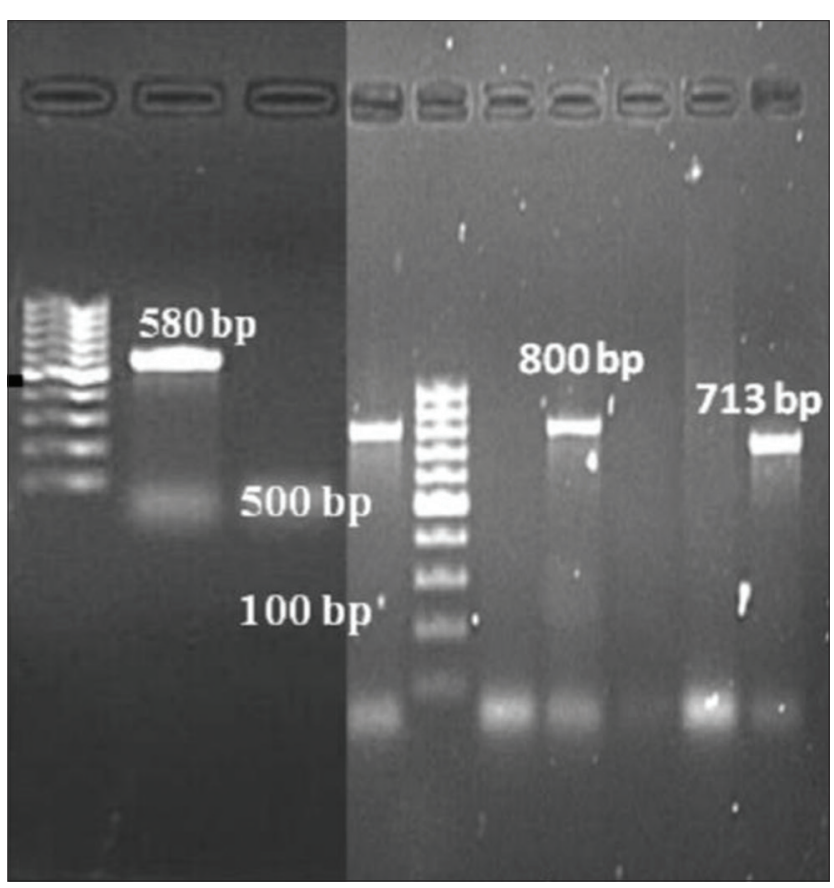

Figure-3: Polymerase chain reaction amplification of bla $_{C T X-M}$ gene (580 bp), bla ${ }_{T E M}(800 \mathrm{bp})$, and bla ${ }_{S H V}(713 \mathrm{bp})$ gene, lane M: 100 bp DNA ladder, lane 1: bla ${ }_{C T X-M}$, lane 3,6: bla $_{T E M}$ isolate, lane 9 bla $_{S H V}$ and lane 2 and 8 : Escherichia coli ATCC 25922.

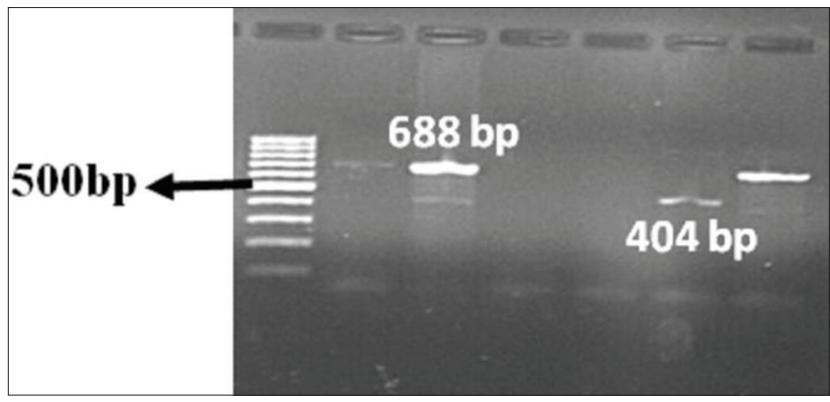

Figure-4: Polymerase chain reaction amplification of bla ${ }_{C T X-M}$ Group 1 and Group 2 gene, lane M: 100 bp DNA ladder, lane 1-6: bla ${ }_{C T X-M}$ Group 1, lane 5 bottom row: bla ${ }_{C t x-M}$ Group 2.

direct correlation whatsoever could be established in the strains clustered together regarding species (cow or buffalo), age, parity of animals, and beta-lactamase gene type. However, it was noticed that most of the isolates with resistant profile $\mathrm{Cep}^{+} \mathrm{Pen}^{+} \mathrm{Tet}^{+}$variants were clustered in clusters 2 and 3, while clusters 4 , 5 , and 6 predominately have $\mathrm{Cep}^{+} \mathrm{Pen}^{+} \mathrm{Tet}^{+} \mathrm{Flu}^{+}$resistance profile.

\section{Discussion}

Even though $E$. coli has been described as a normal inhabitant of the bovine reproductive tract; their role as a major pathogen in clinical endometritis is unchallenged. Beta-lactam antibiotics, especially ceftiofur (third-generation cephalosporin), are currently the treatments of choice for uterine infections in cattle. Extensive use of beta-lactam antibiotics is one of the major attributes for the emergence and spread of ESBL-producing bacterial strains in the recent past. ESBL enzymes confer resistance to extended-spectrum cephalosporins and have an attenuated effect of antibiotic treatment and a high rate of treatment failure. There is a complete lack of scientific information regarding the reports and data reflecting the prevalence of ESBL organisms from bovine uterine infection in India. This study provides information regarding the prevalence of ESBL-producing organisms in the infected uterus of bovines with clinical endometritis and highlights the role of ESBLproducing $E$. coli in the pathogenesis of endometritis.

In this study, bacteria isolated from the uterus of infected postpartum cows and buffaloes demonstrated the dominance of $E$. coli . The present finding extends support to the previous observation of $E$. coli as being the most prevalent organism in bovine, suffering from post-parturient reproductive disorders [32-35]. E. coli commonly found in the gut and integument of animals and the environment. At parturition, massive contamination with these opportunistic organisms in the genital tract leads to endometritis and infertility.

High frequency of resistance against penicillin and cephalosporin class among ESBLs in the current study was in accordance with the similar observation made by others $[13,36]$. Of the 40 isolates, close to $98 \%$ isolates were found to be resistant to at least one of the four cephalosporin antibiotics tested (cefotaxime, ceftriaxone, and cefpodoxime), while $70 \%$ were resistant to all three cephalosporin antibiotics. The antibiogram observed in the current study reflects the findings of other researchers; however, unlike other studies, we have observed a high level of sensitivity to amoxicillin-clavulanic acid and ceftazidime [37]. It was indicated that $45 \%$ of ESBL-producing isolates were also ciprofloxacin-resistant. Cross-resistance with other groups of antibiotics such as fluoroquinolones has been more commonly observed from ESBLproducing bacteria [38].

A perusal of antibiotic susceptibility test result showed that $70 \%(n=28)$ isolates were MDR. This finding correlates with similar results obtained from a study conducted by Sáenz et al. [39] that have reported similar antibiotic resistance profile by $E$. coli isolated from cattle. Ibrahim et al. [36] showed $92 \%$ resistance to at least one antibiotic, $57.9 \%$ showed resistance to three or more antibiotics from three different antibiotic groups. Over recent years, several such studies have highlighted the occurrence of MDR ESBL-producing E. coli isolated from several livestock sources including pigs, poultry, and cattle [16-18].

The prevalence of ESBL-producing E. coli in India has noticeably increased in recent years in animals and associated environment [40]. In our study, the overall percentage of ESBL-producing $E$. coli isolates was $64.5 \%$ (according to the number of investigated strains), at rates similar to those previously reported from other livestock sources [20-25,41]. We compared PCR-based ESBL detection test with ESBL E-test and double-disk synergy test, with regard to their accuracy 


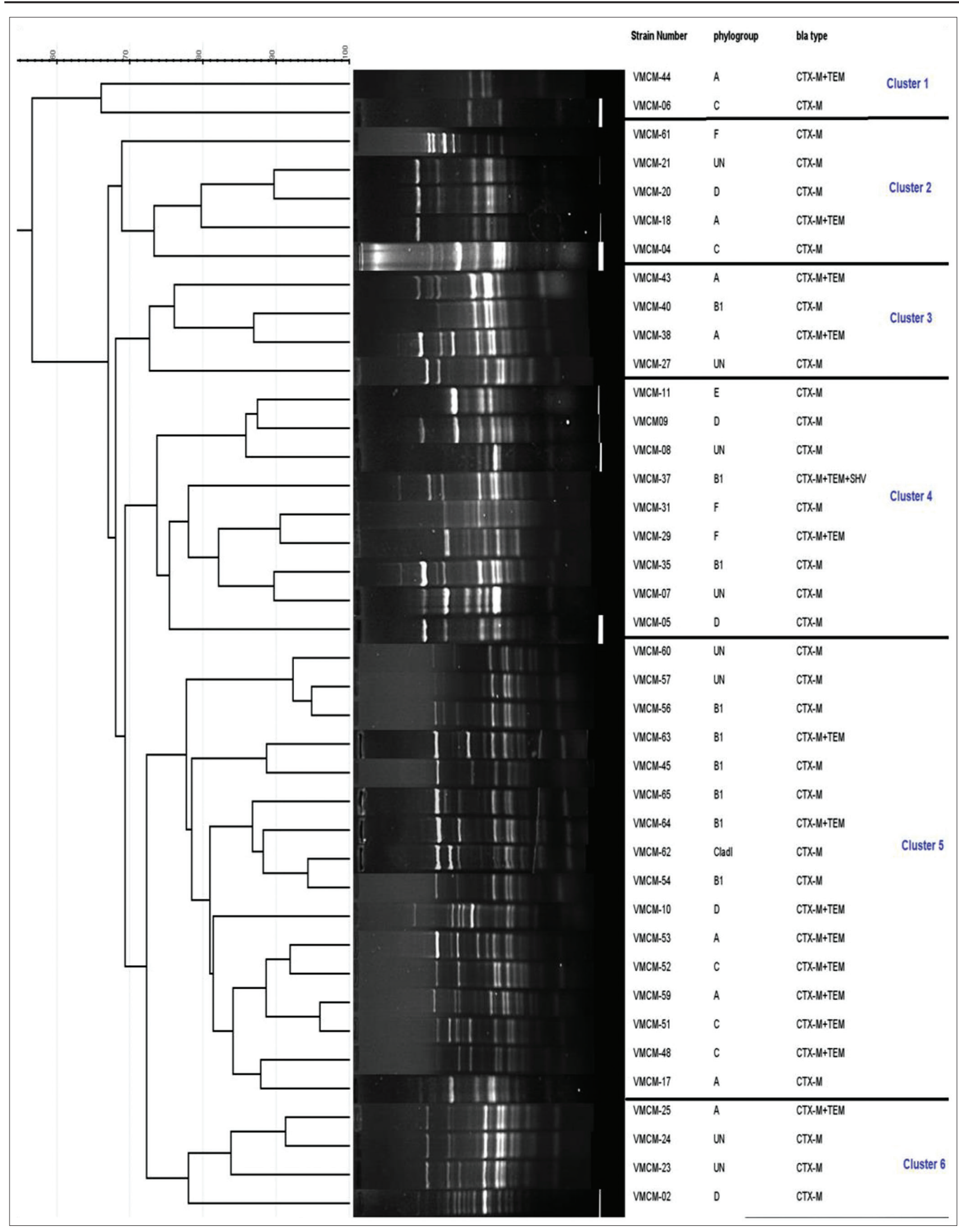

Figure-5: Dendrogram of enterobacterial repetitive intergenic consensus-polymerase chain reaction pattern of extendedspectrum $\beta$-lactamase Escherichia coli strains. The analysis of similarity of the normalized images was accomplished using UPGMA method with arithmetic mean with Dice optimized coefficient.

and effectiveness in detecting ESBL production in $E$. coli. While ESBL E-test could able to detect $100 \%$ isolates as ESBL, $97.5 \%$ isolates were confirmed by the genotypic method as ESBL positive. Positional changes within the beta-lactamase genes are frequently observed to give rise to the variants. These variants are frequently not detected by standard PCR. Doubledisk method and combination disk tests are the least 
accurate as it could able to detect only $77.5 \%$ isolates as ESBL in the present study. A high rate of detection of ESBL by the E-test could be due to the inclusion of false-positive results. Färber et al. [42] reported 6\% false-positive results for ESBL E-test in comparison with ESBL-positive strains confirmed by the genotypic method. Notably, the diagnostic accuracy ESBL E-test is only $94 \%$ when compared with that of the molecular identification method of ESBL production [43]. PCR-based identification of beta-lactamase genes is the most reliable method to identify ESBL-producing Enterobacteriaceae. However, its amalgamation into the routine diagnostic process remains a challenge due to high cost and labor intensiveness.

The most frequent ESBLs in Enterobacteriaceae belong to the TEM, SHV, and CTX-M families. The present study indicates high carriage rates of $b l a_{C T X-M}$ type ESBL (84.5\%) among uterine isolates with bla $a_{C T X-M}$ Group 1 being the major (77.5\%) allele encoding for ESBLs. The findings of this research concur with previous studies around the world $[14,15,17,44]$. In South Asia, $85-90 \%$ of ESBLs carry bla ${ }_{C T X-M}$ genotypes $[45,46]$. Of the $b l a_{C T X-M}$ genes, those belonging to the $b l a_{C T X-M}$ Group 1 are the most widespread genes encoding for ESBLs $[13,40]$.

Most of E. coli isolates can be categorized into several phylogenetic groups, namely, A, B1, B2, C, $\mathrm{D}, \mathrm{E}$, and $\mathrm{F}$ [47]. The previous findings are compatible with the results of our study in which $E$. coli isolates associated with clinical endometritis mainly belonged to phylogroup A, while phylogroup B2 was not detected [48-51]. Phylogenetic groups A and B1 were mostly associated with commensal and diarrheagenic strains, whereas the close association of phylogenetic groups B2 and D was established in extraintestinal infections and invasive strains [52]. Hence, the colonization of phylogenetic groups A and B1 in the uterus can be corroborated with the fact that postpartum fecal contamination of uterus remains the most remarkable cause of clinical endometritis. ERIC-PCR analysis of $E$. coli isolates revealed that, nevertheless, the isolates were from a narrow geographical boundary that the strains were genetically heterogeneous. From this study, we observe that there is no correlation of the clonally related strains with their respective phylogroup, the pattern of the beta-lactamase gene content. Several isolates showed common banding pattern indicating the dissemination of clonally related organisms between the host animals. Antibiotic selection pressure could be the most important attribute for the spread and occurrence of clonally similar groups among these isolates in the absence of correlation with their respective antibiogram or with the type of beta-lactamases gene they harbor. Although ERIC profiling reflects true genetic relatedness of a group of bacterial isolates, its usefulness for molecular epidemiological investigation of antimicrobial-resistant isolates holds limited value. Despite the fact that
ERIC-PCR demonstrates reasonable high level of concordance, discrimination, and typeability, pulsefield gel electrophoresis and multilocus sequence typing are better suited for inferring relatedness among isolates.

\section{Conclusion}

The present study highlights a high prevalence of ESBL-producing $E$. coli associated with postpartum uterine infections in bovine. A high level of resistance was observed for the third-generation cephalosporin, which is the treatment of choice for such infection in bovines. The colonization of these bacteria significantly affects the clinical outcome of treatment using cephalosporin antibiotics and warrants an alternate line of treatment.

\section{Authors' Contributions}

SA, APS, and RS contributed to the study conception. SA, RaS, and JA contributed in sample collection. SC and RS designed and conducted the experiments. APS and SNP analyzed the data. APS drafted the manuscript. AS edited the manuscript. All authors read and approved the final manuscript.

\section{Acknowledgments}

Financial assistance from the Indian Council of Agricultural Research, New Delhi, India, under the Outreach Programme on Ethnoveterinary Medicine (Grant No. 1-72/(EVM-Outreach Programme)/2009/ Med dated 05.02.2010) to the Department of Veterinary Pharmacology and Toxicology, DUVASU, Mathura, India, is duly acknowledged. The authors are also thankful to Vice-chancellor, U.P. Pandit Deen Dayal Upadhyaya Pashu Chikitsa Vigyan Vishwavidhyalaya Ewam Gau Anusandhan Sansthan Mathura, 281001 (UP), for providing infrastructural facility to review this study.

\section{Competing Interests}

The authors declare that they have no competing interests.

\section{Publisher's Note}

Veterinary World remains neutral with regard to jurisdictional claims in published institutional affiliation.

\section{References}

1. Dinani, O.P., Tyagi, P.K., Giri, A.K. and Popat, D.S. (2018) Role of livestock in doubling the farmers' income-national perspective and the way forward. Int. J. Environ. Sci., 7(2): 496-504.

2. Sheldon, I.M., Cronin, J.G. and Bromfield, J.J. (2019) Tolerance and innate immunity shape the development of postpartum uterine disease and the impact of endometritis in dairy cattle. Annu. Rev. Anim. Biosci., 7(1): 361-384.

3. Azawi, O.I., Omran, S.N. and Hadad, J.J. (2008) A study on repeat breeding of Iraqi buffalo cows. Buffalo Bull., 27(4): 274-284.

4. Elliott, L., McMahon, K.J., Gier, H.T. and Marion, G.B. (1968) Uterus of the cow after parturition: Bacterial content. 
Am. J. Vet. Res., 29(1): 77-81.

5. Griffin, J.F.T., Hartigan, P.J. and Nunn, W.R. (1974) Nonspecific uterine infection and bovine fertility: I. Infection patterns and endometritis during the first seven weeks postpartum. Theriogenology, 1(3): 91-106.

6. Sheldon, I.M., Noakes, D.E., Rycroft, A.N., Pfeiffer, D.U. and Dobson, H. (2002) Influence of uterine bacterial contamination after parturition on ovarian dominant follicle selection and follicle growth and function in cattle. Reproduction, 123(6): 837-845.

7. Williams, A.E. and Davison, T.F. (2005) Enhanced immunopathology induced by very virulent infectious bursal disease virus. Avian Pathol., 34(1): 4-14.

8. Ma, Z., Ginn, A., Kang, M., Galvão, K.N. and Jeong, K.C. (2018) Genomic and virulence characterization of intrauterine pathogenic Escherichia coli with multi-drug resistance isolated from cow uteri with metritis. Front. Microbiol., 9: 3137.

9. Mandhwani, R., Bhardwaz, A., Kumar, S., Shivhare, M. and Aich, R. (2017) Insights into bovine endometritis with special reference to phytotherapy. Vet. World, 10(12): 1529-1532.

10. Zhao, S., White, D.G., McDermott, P.F., Friedman, S., English, L., Ayers, S., Meng, J., Maurer, J.J., Holland, R. and Walker, R.D. (2001) Identification and expression of cephamycinase bla (CMY) genes in Escherichia coli and Salmonella isolates from food animals and ground meat. Antimicrob. Agents Chemother., 45(12): 3647-3650.

11. Li, X.Z., Mehrotra, M., Ghimire, S. and Adewoye, L. (2007) Beta-Lactam resistance and beta-lactamases in bacteria of animal origin. Vet. Microbiol.,121(3-4): 197-214.

12. Perez, F., Endimiani, A., Hujer, K.M. and Bonomo, R.A. (2007) The continuing challenge of ESBLs. Curr. Opin. Pharmacol., 7(5): 459-469.

13. Ur Rahman, S., Ali, T., Ali, I., Khan, N.A., Han, B. and Gao, J. (2018) The growing genetic and functional diversity of extended-spectrum beta-lactamases. Biomed. Res. Int., 2018: 9519718

14. Dahmen, S., Métayer, V., Gay, E., Madec, J.Y. and Haenni, M. (2013) Characterization of extended-spectrum beta-lactamase (ESBL)-carrying plasmids and clones of Enterobacteriaceae causing cattle mastitis in France. Vet. Microbiol., 162(2-4): 793-799.

15. Geser, N., Stephan, R. and Hächler, H. (2012) Occurrence and characteristics of extended-spectrum $\beta$-lactamase (ESBL) producing Enterobacteriaceae in food-producing animals, minced meat and raw milk. BMC Vet. Res., 8(1): 21 .

16. Timofte, D., Maciuc, I.E., Evans, N.J., Williams, H., Wattret, A., Fick, J.C. and Williams, N.J. (2014) Detection and molecular characterization of Escherichia coli CTX-M15 and Klebsiella pneumoniae SHV-12 $\beta$-lactamases from bovine mastitis isolates in the United Kingdom. Antimicrob. Agents Chemother., 58(2): 789-794.

17. Kar, D., Bandyopadhyay, S., Bhattacharyya, D., Samanta, I., Mahanti, A., Nanda, P.K., Mondal, B., Dandapat, P., Das, A.K., Dutta, T.K., Bandyopadhyay, S. and Singh, R.K. (2015) Molecular and phylogenetic characterization of multidrug-resistant extended-spectrum beta-lactamase producing Escherichia coli isolated from poultry and cattle in Odisha, India. Infect. Genet. Evol., 29(1): 82-90.

18. Xu, G., An, W., Wang, H. and Zhang, X. (2015) Prevalence and characteristics of extended-spectrum $\beta$-lactamase genes in Escherichia coli isolated from piglets with post-weaning diarrhoea in Heilongjiang province, China. Front. Microbiol., 6: 1103.

19. Ewers, C., Bethe, A., Semmler, T., Guenther, S. and Wieler, L.H. (2012) Extended-spectrum $\beta$-lactamase-producing and AmpC-producing Escherichia coli from livestock and companion animals, and their putative impact on public health: A global perspective. Clin. Microbiol. Infect., 18(7): 646-655.
20. Lalzampuia, H., Dutta, T.K., Warjri, I. and Chandra, R. (2013) PCR-based detection of extended-spectrum $\beta$-lactamases (bla CTX-M-1and bla TEM) in Escherichia coli, Salmonella spp. and Klebsiella pneumoniae isolated from pigs in North Eastern India (Mizoram). Indian J. Microbiol., 53(3): 291-296.

21. Lalzampuia, H., Dutta, T.K., Warjri, I. and Chandra, R. (2014) Detection of extended-spectrum $\beta$-lactamases $\left(\right.$ bla $_{C T X M-1}$ and bla $\left.{ }_{\text {TEM }}\right)$ in Escherichia coli, Salmonella spp. and Klebsiella pneumoniae isolated from poultry in North Eastern India. Vet. World, 7(11): 110-113.

22. Ghatak, S., Singha, A., Sen, A., Guha, C., Ahuja, A., Bhattacharjee, U., Das, S., Pradhan, N.R., Puro, K., Jana, C., Dey, T.K., Prashantkumar, K.L., Das, A., Shakuntala, I., Biswas, U. and Jana, P.S. (2013) Detection of New Delhi metallo-beta-lactamase and extended-spectrum beta-lactamase genes in Escherichia coli isolated from mastitic milk samples. Transbound. Emerg. Dis., 60(5): 385-389.

23. Bandyopadhyay, S., Banerjee, J., Bhattacharyya, D., Samanta, I., Mahanti, A., Dutta, T.K., Ghosh, S., Nanda, P.K., Dandapat, P. and Bandyopadhyay, S. (2018) Genomic identity of fluoroquinolone-resistant bla $_{C T X-M-15^{-}}$ type ESBL and pMAmpC $\beta$-lactamase producing Klebsiella pneumoniae from buffalo milk, India. Microb. Drug Resist., 24(9): 1345-1353.

24. Bora, A., Hazarika, N.K., Shukla, S.K., Prasad, K.N., Sarma, J.B. and Ahmed, G. (2014) Prevalence of bla blaSHV and blaCTX-M genes in clinical isolates of Escherichia coli and Klebsiella pneumoniae from Northeast India. Indian J. Pathol. Microbiol., 57(2): 249-254.

25. Samanta, I., Joardar, S.N., Das, P.K. and Sar, T.K. (2015) Comparative possession of Shiga toxin, intimin, enterohaemolysin and major extended-spectrum beta-lactamase (ESBL) genes in Escherichia coli isolated from backyard and farmed poultry. Iran. J. Vet. Res., 16(1): 90-93.

26. Cowan, S.F. and Steel, K.J. (1970) In: Barrow, G.I. and Feltham, R.K.A., editors. Manual for the Identification of the Medical Bacteria $3^{\text {rd }}$ ed. Cambridge University, Cambridge.

27. CLSI. (2017) Performance Standards for Antimicrobial Susceptibility Testing. Clinical and Laboratory Standards Institute (M100eS22), S27 ${ }^{\text {nd }}$ Informational Supplement.

28. Clermont, O., Christenson, J.K., Denamur, E. and Gordon, D.M. (2013) The clermont Escherichia coli phylo-typing method revisited: Improvement of specificity and detection of new phylogroups. Environ. Microbiol. Rep., 5(1): 58-65.

29. Hopkins, K.L., Wootton, L., Day, M.R. and Threlfall, E.J. (2007) Plasmid-mediated quinolone resistance determinant qnrS1 found in Salmonella enterica strains isolated in the UK. J. Antimicrob. Chemother., 59(6): 1071-1075.

30. Dallenne, C., da Costa, A., Decré, D., Favier, C. and Arlet, G. (2010) Development of a set of multiplex PCR assays for the detection of genes encoding important $\beta$-lactamases in Enterobacteriaceae. J. Antimicrob. Chemother., 65(3): 490-495.

31. Durmaz, S., Bal, E.B.B., Gunaydin, M., Yula, E. and Percin, D. (2015) Detection of $\beta$-lactamase genes, ERICPCR typing and phylogenetic groups of ESBL producing quinolone-resistant clinical Escherichia coli isolates. Biomed. Res., 26(1): 43-50.

32. Ata, A., Türütoğlu, H., Kale, M., Gülay, M.Ş. and Pehlivanoğlu, F. (2010) Microbial flora of normal and abnormal cervical mucous discharge associated with reproductive performance of cows and heifers in estrus. Asian Australas J. Anim. Sci., 23(8): 1007-1012.

33. Debnatha, S.K., Mattrab, C., Kabirc, S.M.L. and Ahmed, J.U. (2012) Occurrence of reproductive disorders in post parturient cows with special emphasis on vaginal culture in some selected Upazilas of Bangladesh. Sci. J. Vet. $A d v ., 1(4): 110-116$.

34. Wang, M.L., Liu, M.C., Xu, J., An, L.G., Wang, J.F. and 
Zhu, Y.H. (2018) Uterine microbiota of dairy cows with clinical and subclinical endometritis. Front. Microbiol., 9: 2691.

35. Palanisamy, K., Udhayavel, S., Malmarugan, S. and Rajeswar, J. (2013) Antibiogram pattern of bacteria causing endometritis in cows. Vet. World, 6(1): 100.

36. Ibrahim, D.R., Christine, E.R.D., Stekel, D.J., Ramsden, S.J. and Hobman, J.L. (2016) Multidrug-resistant, extended-spectrum $\beta$-lactamase (ESBL)-producing Escherichia coli isolated from a dairy farm. FEMS Microbiol. Ecol., 92(4): fiw013.

37. Singh, B.R. (2014) Carriage of multiple drug-resistant bacteria in vagina of apparently healthy swamp buffaloes in Nagaland. Adv. Anim. Vet. Sci., 2(5): 292-295.

38. Colodner, R. (2005) Extended-spectrum $\beta$-lactamases: A challenge for clinical microbiologists and infection control specialists. Am. J. Infect. Control., 33(2): 104-107.

39. Sáenz, Y., Zarazaga, M., Brias, L., Lantero, M., RuizLarrea, F. and Torres, C. (2001) Antibiotic resistance in Escherichia coli isolates obtained from animals, foods and humans in Spain. Int. J. Antimicrob. Agents., 18(4): 353-358

40. Rao, L., Lv, L., Zeng, Z., Chen, S., He, D., Chen, X., Wu, C., Wang, Y., Yang, T., Wu, P., Liu, Y. and Liu, J.H. (2014) Increasing prevalence of extended-spectrum cephalosporin-resistant Escherichia coli in food animals and the diversity of CTX-M genotypes during 2003-2012. Vet. Microbiol., 172(3-4): 534-541.

41. Karuppasamy, C., Ralte, L., Malsawtluangi, L. and Chawang, S. (2014) Prevalence of extended-spectrum beta-lactamase (ESBL) producing pathogens in raw milk samples collected from Aizawl town, Mizoram, Indian J. Fundam. Appl. Life Sci., 5(1): 332-340.

42. Färber, J., Moder, K.A., Layer, F., Tammer, I., König, W. and König, B. (2008) Extended-spectrum beta-lactamase detection with different panels for automated susceptibility testing and with a chromogenic medium. J. Clin. Microbiol., 46(11): 3721-3727.

43. Wiegand, I., Geiss, H.K., Mack, D., Stürenburg, E. and Seifert, H. (2007) Detection of extended-spectrum beta-lactamases among Enterobacteriaceae by use of semiautomated microbiology systems and manual detection procedures. J. Clin. Microbiol., 45(4): 1167-1174.

44. Locatelli, C., Caronte, I., Scaccabarozzi, L., Migliavacca, R.,
Pagani, L. and Moroni, P. (2009) Extended-spectrum $\beta$-lactamase production in E. coli strains isolated from clinical bovine mastitis. Vet. Res. Commun., 33(1): 141-144.

45. Horner, C., Fawley, W., Morris, K., Parnell, P., Denton, M. and Wilcox, M. (2014) Escherichia coli bacteraemia: 2 years of prospective regional surveillance (2010-12). $J$. Antimicrob. Chemother., 69(1): 91-100.

46. Reuland, E.A., Al Naiemi, N., Kaiser, A.M., Heck, M., Kluytmans, J.A.J., Savelkoul, P.H.M., Elders, P.J.M. and Vandenbroucke-Grauls, C.M.J. (2016) Prevalence and risk factors for carriage of ESBL-producing Enterobacteriaceae in Amsterdam. J. Antimicrob. Chemother., 71(4): 1076-1082.

47. Nowak, K., Fahr, J., Weber, N., Lübke-Becker, A., Semmler, T., Weiss, S., Mombouli, J.V., Wieler, L.H., Guenther, S., Leendertz, F.H. and Ewers C. (2017) Highly diverse and antimicrobial susceptible Escherichia coli display a naïve bacterial population in fruit bats from the Republic of Congo. PLoS One, 12(7): e 0178146.

48. Silva, E., Leitão, S., Tenreiro, T., Pomba, C., Nunes, T., Lopes da Costa, L. and Mateus, L. (2009) Genomic and phenotypic characterization of Escherichia coli isolates recovered from the uterus of puerperal dairy cows. J. Dairy Sci., 92(12): 6000-6010.

49. Yang, L.M., Wang, Y.H., Peng, Y., Min, J.T., Hang, S.Q. and Zhu, W.Y. (2016) Genomic characterization and antimicrobial susceptibility of bovine intrauterine Escherichia coli and its relationship with postpartum uterine infections. J. Integr. Agric., 15(6): 1345-1354.

50. Luque, A.T., Moreno, C.G., Pasteris, S.E., Orden, J.A., de la Fuente, R. and Otero, M.C. (2017) Antimicrobial-resistant Escherichia coli in the reproductive tract microbiota of cows and sows. Comp. Immunol. Microbiol. Infect. Dis., 55(1): 13-19.

51. de Cássia Bicudo, L., Oba, E., Bicudo, S.D., da Silva Leite, D., Siqueira, A.K., de Souza Monobe, M.M., Nogueira, M., de Figueiredo Pantoja, J.C., Listoni, F.J.P. and Ribeiro, M.G. (2019) Virulence factors and phylogenetic group profile of uterine Escherichia coli in early postpartum of high-producing dairy cows. Anim. Prod. Sci., 59(10): 1898-1905.

52. Liu, Y., Liu, G., Liu, W., Liu, Y., Ali, T., Chen, W., Yin, J. and Han, B. (2014) Phylogenetic group, virulence factors and antimicrobial resistance of Escherichia coli associated with bovine mastitis. Res. Microbiol., 165(4): 273-277. 